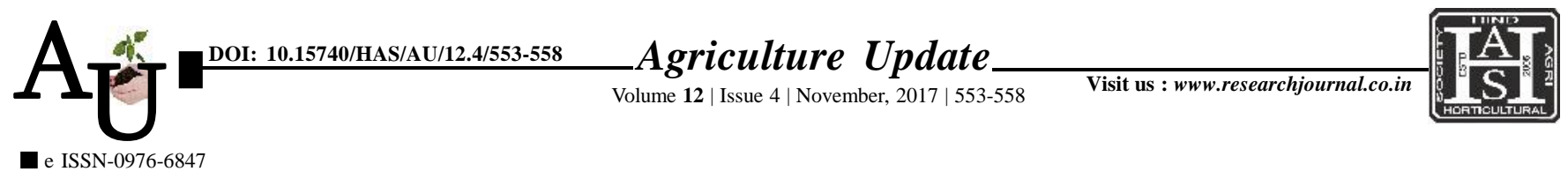

\title{
Research Article: Study on the functioning of SHG group and opinion of non-participating respondents on lac production of participating women lac growers
}

\author{
MANOHER SARYAM, MONI THOMAS AND S.K. AGRAWAL
}

Article Chronicle :

Received :

01.07.2017;

Revised :

25.08.2017;

Accepted :

11.09.2017

Key Words : Self-help group, Investment, Income, Empowerment, Nonparticipants, Women lac growers

Author for correspondence :

MANOHER SARYAM Department of Extension Education, Institute of Agricultural Sciences, Banaras Hindu University, VARANASI

(U.P.) INDIA

Email:manohar.saryam@ gmail.com

See end of the article for authors' affiliations
SUMMARY : The participation of women in self-help groups (SHGs) made a significant impact on their empowerment both in social and economic aspects. This study addresses women empowerment through self-help groups in Seoni district of Madhya Pradesh. Self-help groups (SHGs) are becoming one of the important means for the empowerment of poor women in almost all the developing countries including India. Madhya Pradesh is no exception as regards the role played by women's collectives, known by different names for emancipation and empowerment of poor women. This study conducted in the year 2013 in Seoni district of Madhya Pradesh in India. Study revealed that fifty per cent lac growers had high level innovativeness, $(60 \%)$ lac growers in the low aspiration level, among the eight components of lac production identified, it was found that all the lac growers had a good knowledge on all components. However, knowledge on the spray of pesticide was partial among 40 per cent lac growers and 30 per cent had poor knowledge on it. Majority (80\%) of the members of lac growers, before adoption lac production were practicing agriculture+labour, and only 20 per cent engaged in agriculture. After adopting lac production, there was a shift in the livelihood pattern as 60 per cent of them adopted lac production+ agriculture + labour while remaining 40 per cent were engaged agriculture + lac production. Mahalaxmi Adivasi Mahila Lac Utpadak has grown upto be a matured SHG, since its formation in 2005-06. Its functioning's are conducting regular meeting of the SHG conducts, maintenance of bank account and profit sharing and market survey for current lac price in Mandis. All the young non- participating respondents were of the opinion that participating women lac growers increased their investments in agriculture, but only 58.33 per cent agreed on their diversified activities.Middle aged non- participating respondents were of the opinion that participating women lac growers increased investment in agriculture, but 91.66 per cent agreed on their diversified activities. Old aged nonparticipating respondents were of the opinion that participating women lac growers investment in agriculture, but 83.33 per cent agreed their diversified activities.

How to cite this article : Saryam, Manoher, Thomas, Moni and Agrawal, S.K. (2017). Study on the functioning of SHG group and opinion of non-participating respondents on lac production of participating women lac growers. Agric. Update, 12(4): 553-558; DOI : 10.15740/HAS/AU/12.4/553-558. 